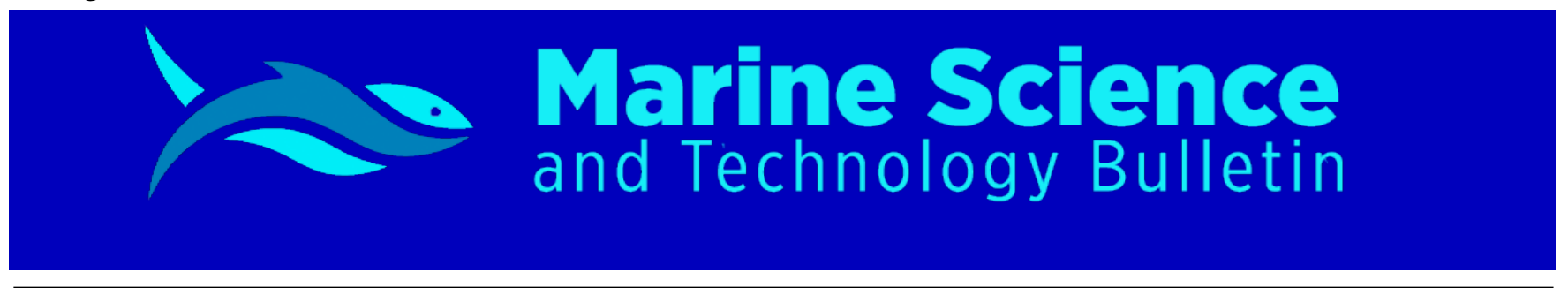

RESEARCH ARTICLE

\title{
Seasonal population patterns of Holothuria Arenicola Semper, 1868 from Karachi coast, Northern Arabian Sea
}

\author{
Quratulan Ahmed $^{1^{*}}$ (D) Semra Benzer ${ }^{2}$ (D) $\cdot$ Qadeer Mohammad Ali $^{1}$ (D) \\ ${ }^{1}$ The Marine Reference Collection and Resource Centre, University of Karachi, 75270, Karachi, Pakistan \\ ${ }^{2}$ Gazi University, Education Faculty, Science Education, Teknikokullar 06500, Ankara, Turkey
}

\begin{tabular}{l} 
A R T I C L E I N F O \\
\hline Article History: \\
Received: 17.06 .2020 \\
Received in revised form: 12.08 .2020 \\
Accepted: 18.08 .2020 \\
Available online: 19.08 .2020 \\
\hline
\end{tabular}

Keywords:
Arabian Sea
Holothuria arenicola
Karachi coast
Population
Sand cucumber

\begin{abstract}
A B S T R A C T
The present study was carried out to assess the reproduction weight-length based growth and condition factor of Holothuria arenicola Semper, 1868, from January to December 2018, in Karachi coast, Northern Arabian Sea. The sex percentage was determined as $33.3 \%$ females and $66.7 \%$ males. Length of specimens ranged from 14 and $38 \mathrm{~cm}$ and weight of specimens ranged from 21 and $82 \mathrm{~g}$. The relationship was $\mathrm{W}=2.408 \mathrm{~L}^{0.9482}\left(\mathrm{R}^{2}=0.999\right)$ for females, $\mathrm{W}=0.989 \mathrm{~L}^{0.9482}\left(\mathrm{R}^{2}=0.998\right)$ for males and $\mathrm{W}=1.234 \mathrm{~L}^{1.1565}\left(\mathrm{R}^{2}=0.999\right)$ for all individual. The condition factor ranged between 0.84 and 2.62 (mean: $1.52 \pm 0.70$ ) in females and between 0.83 and 2.67 (mean: 1.43 \pm 0.71 ) in males. The gonadosomatic index of specimens ranged between 5.50 and 10.66 (mean: $7.95 \pm 1.24$ ). The gutted weight of specimens ranged between 2.10 and $11.44 \mathrm{~g}$ (mean: $4.91 \pm 1.77)$. Studies about environmental variables and characteristics are necessary in order to complement the understanding of reproduction, the length-weight relationships and condition of sea cucumber in Karachi coast.
\end{abstract}

Please cite this paper as follows:

Ahmed, Q., Benzer, S., Ali, Q. M. (2020). Seasonal population patterns of Holothuria arenicola Semper, 1868 from Karachi coast,

Northern Arabian Sea. Marine Science and Technology Bulletin, 9(2): 188-194.

\section{Introduction}

Holothuria arenicola Semper, 1868 commonly called the sand cucumber and been on the IUCN Red List (DD - Data Deficient) is commercially important (Conand and Gamboa, 2013). It distributed at some localities in the Western Pacific, including the Red Sea, parts of Asia, the Indian Ocean, the
Comoros, along the Pacific coast of Central America, Caribbean and Brazil (Purcell et al., 2012). This species is found in substantially in coastal waters of Pakistan (Tahera and Tirmizi, 1995). Abundant in shallow areas but can also be found in deeper waters, under stones, in coral debris and on sand flats (Mosher, 1980).

\footnotetext{
* Corresponding author

E-mail address: quratulana@gmail.com (Q. Ahmed)
} 
Relatively little information is available on the biology and ecology of these sea cucumbers belong to the class Holothuroidea in the northern Arabian Sea coasts of Pakistan. $H$. arenicola is also found from the Indo-Pacific to the tropical Western Atlantic. The species is reported from tropical Australia, Mozambique, the Red Sea, Ascension Island, Virgin Islands, Antigua, Barbados, Tobago, Belize, Bermuda, Tortugas, Jamaica, Puerto Rico, U.S. (Mosher, 1980).

Sea cucumber hunting is an important source of income for many other communities (Clarke, 2004). Although there are about 66 species of sea cucumbers in the world (Purcell, 2010), important biological parameters for most species are not known. One of these parameters is the allometric coefficient, which is obtained from length-weight relationships (Gerritsen and McGrath, 2007).

The length weight relation (LWR) is an important tool to estimate attributes of the population (Le Cren, 1951; Giacalone et al., 2010). In the literature, there are some studies about some parameters of sea cucumber such as length and weight (Kilada et al., 2000; Purcell and Tekanene, 2006; Herrero Pérezrul and Reyes-Bonilla, 2008; Kazanidis et al., 2010; Hannah et al., 2012; Siddique et al., 2014; Poot-Salazar et al., 2014; Natan et al., 2015; Aydin, 2016; Ram et al., 2016; Ahmed et al., 2016; Ahmed et al., 2018a, 2018b; Siddique and Ayub, 2019).

This study includes the length, weight, condition, gonadosomatic index, gutted weight parameters and length weight relations study on the population of Holothuria arenicola from Karachi coast of Pakistan.

\section{Material and Methods}

\section{Sample Collection and Identification}

A total of 81 Holothuria arenicola was collected from Buleji (Rocky Shore) (2450'20.41” N, 66 $49^{\circ} 24.15^{\prime \prime}$ E) of Karachi, Pakistan, the area has approximately eight hundred (800) meters long and one hundred fifty (150) meters wide shown in Figure 1 and Figure 2. Ten (10) surveys were conducted from January to December 2018 on seasonal basis, pre-monsoon (March to May), Southwest monsoon (June to September) post-monsoon (October and November) and Northeast monsoon (December to February).

Specimens were collected by hand and transferred to the laboratory in well aerated aquarium for taxonomic studies, morphological features and microscopic examinations were conducted under a microscope at 10×10 magnifications (Nikon LABOPHOT-2). Length $(\mathrm{cm})$ and weight $(\mathrm{g})$ of specimen were measured. Total length from mouth to anus was measured to the flexible ruler and wet weight, gutted weight was measured to the nearest $0.01 \mathrm{~g}$ immediately after removing the animal from the water to avoid evisceration.

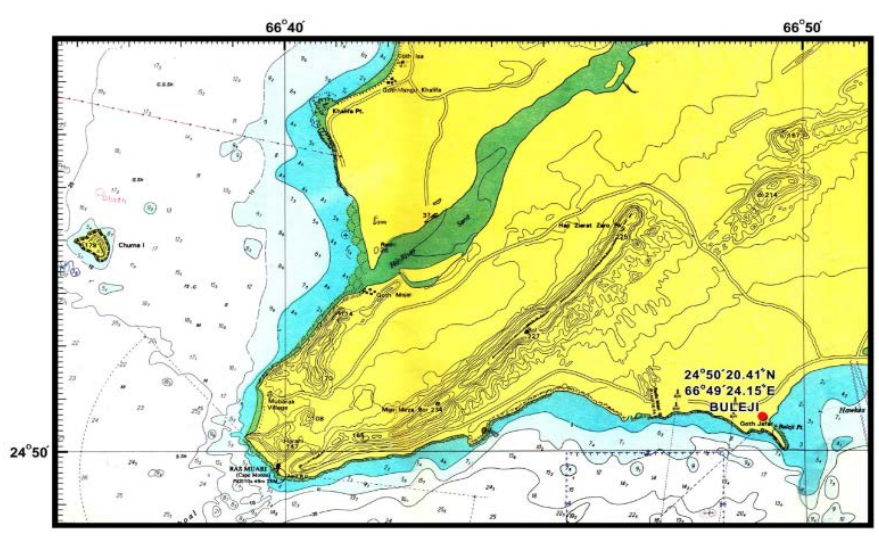

Figure 1. Study area map (Buleji) Karachi coast

\section{Data Analysis}

They were grouped according to their weight and length relationships (Chuqunova, 1963). The growth in length and weight were shown in absolute and relative growth parameters. The growth equation of the sea cucumbers equation 1 was derived from equation 2 (Le Cren, 1951).

$$
\begin{gathered}
W=a \times L^{b} \\
W=\log a+b \log L
\end{gathered}
$$

Here, $W$ represents the weight " $a$ " and " $b$ " are the coefficients of the logarithmic equation. Fulton's condition factor is widely used in fisheries and general fish biology studies. This factor is calculated from the relationship between the weight of sea cucumbers and its length, with the intention of describing the "condition" of that individual. The formula is of the form:

$$
C=\frac{W}{L^{b}}
$$

where $C$ is Fulton's condition factor, $b=1.1565$ for males + females, $b=0.9482$ for females, and $b=1.2214$ for males. $W$ is the weight of sea cucumbers, and $L$ is the length. For calculating gonadosomatic index (GSI) the following formula was used:

$$
G S I=\frac{\text { Weight of ovary }}{\text { Weight }} \times 100
$$

\section{Statistical Analysis}

Statistical analysis of data (difference between sexes, seasonal difference) was carried out using SPSS statistical package program for Mac Ver. 23. 

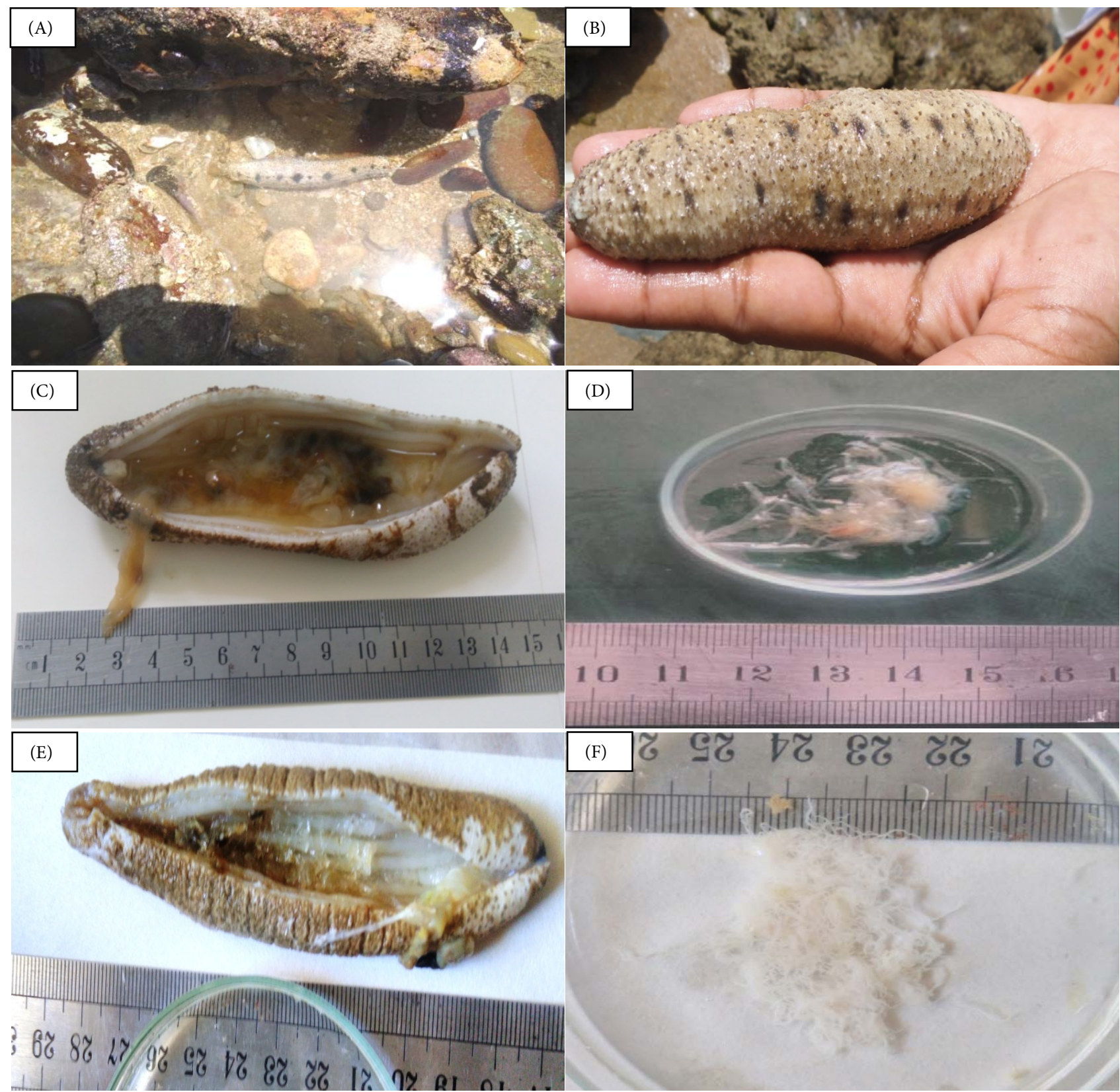

Figure 2. Holothuria arenicola. (A) H. arenicola with its habitat on Buleji coast, (B) H. arenicola dorsal view, (C) $H$. arenicola (female), (D) Gonads (female), (E) H. arenicola (Male), (F) Gonads (Male)

\section{Results}

There were about $33.33 \%$ females and $66.66 \%$ males (sex ratio 1:2). The sex distribution of all specimens examines are shown in Table 1. The lengths of specimens ranged between 14 and $38 \mathrm{~cm}$ (mean: $22.97 \pm 5.65$ ). The weight of specimens varied

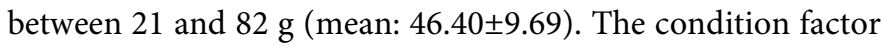
ranged between 0.84 and 2.62 (mean: $1.52 \pm 0.70$ ) in females and between 0.83 and 2.67 (with average $1.43 \pm 0.71$ ) in males. The gonadosomatic index (GSI) of specimens ranged between 5.50 and 10.66 (mean: 7.98 \pm 1.24 ). The gutted weight of specimens ranged between 2.10 and $11.44 \mathrm{~g}$ (mean: 4.91 1.77 ) (Table 1). The differences between the genders were insignificant in terms of length, weight, gonadosomatic index and gut weight in all season ( $p>0.05$, ANOVA). The differences between the genders were found significant in terms of condition in all seasons $(\mathrm{p}<0.05$, ANOVA).

Length-weight relationships were calculated using the data of all sea cucumber individuals. The relationship was $\mathrm{W}=2.40848216 \mathrm{~L}^{0.9482}\left(\mathrm{R}^{2}=0.999\right)$ for females, $\mathrm{W}=0.9893513 \mathrm{~L}^{1.2214}\left(\mathrm{R}^{2}=0.998\right)$ for males and $\mathrm{W}=1.23371441 \mathrm{~L}^{1.1565}\left(\mathrm{R}^{2}=0.999\right)$ for all individuals. This may be due the cylindrical shape of the animal (Conand, 1989) and it means also that length dose that not grows at the same rate of the weight. Length-weight curves for males and females are drawn in Figure 3. 
Table 1. The distribution of sea cucumbers of season, sex, length, weight, condition, gonadosomatic index and gutted weight

\begin{tabular}{|c|c|c|c|c|c|c|c|}
\hline Season & Sex & $\mathbf{N}$ & $\begin{array}{c}\mathrm{L}(\mathrm{cm}) \\
\text { min-max } \\
\text { Average } \pm S D\end{array}$ & $\begin{array}{c}\text { W }(g) \\
(\min -\mathbf{m a x}) \\
\text { Average } \pm S D\end{array}$ & $\begin{array}{c}\text { C } \\
(\min -\mathbf{m a x}) \\
\text { Average } \pm S D\end{array}$ & $\begin{array}{c}\text { GSI } \\
(\min -\mathbf{m a x}) \\
\text { Average } \pm \text { SD }\end{array}$ & $\begin{array}{c}\text { GtW } \\
(\min -\mathbf{m a x}) \\
\text { Average } \pm \text { SD }\end{array}$ \\
\hline \multirow[t]{2}{*}{ Monsoon } & $0^{\pi}$ & 6 & $15.50-24.00 / 20.17 \pm 2.99$ & $23.00-52.00 / 40.50 \pm 9.65$ & $0.84-1.07 / 1.02 \pm 0.09$ & $6.83-9.23 / 7.91 \pm 0.94$ & $2.50-4.80 / 3.78 \pm 0.78$ \\
\hline & \$० & 11 & $15.00-27.00 / 20.58 \pm 3.30$ & $23.00-58.00 / 41.46 \pm 8.97$ & $0.84-2.61 / 1.68 \pm 0.07$ & $6.31-9.23 / 7.79 \pm 0.89$ & $2.50-4.80 / 3.80 \pm 0.64$ \\
\hline Monsoon & 90" & 30 & $14.00-33.00 / 21.62 \pm 5.40$ & $21.00-71.00 / 44.03 \pm 13.30$ & $0.83-2.67 / 1.59 \pm 0.07$ & $5.50-10.37 / 7.48 \pm 1.34$ & $2.10-9.80 / 4.59 \pm 1.81$ \\
\hline Post & q & 4 & $17.50-29.00 / 22.95 \pm 5.44$ & $36.00-54.00 / 45.70 \pm 8.65$ & $2.27-2.53 / 2.42 \pm 0.11$ & 7.07-9.26/7.98 \pm 0.95 & $3.80-5.70 / 4.55 \pm 0.81$ \\
\hline \multirow[t]{2}{*}{ Monsoon } & $0^{\pi}$ & 15 & $19.30-32.00 / 25.88 \pm 5.14$ & $41.00-67.00 / 52.53 \pm 9.55$ & $0.89-1.10 / 1.00 \pm 0.08$ & $6.34-10.66 / 8.57 \pm 1.40$ & $3.40-7.80 / 5.80 \pm 1.55$ \\
\hline & $90^{7}$ & 19 & $17.50-32.00 / 25.26 \pm 5.20$ & $36.00-67.00 / 51.11 \pm 9.56$ & $0.89-2.53 / 1.30 \pm 0.60$ & $6.34-10.66 / 8.45 \pm 1.33$ & $3.40-7.80 / 5.54 \pm 1.50$ \\
\hline All & q & 27 & $14.00-38.00 / 23.72 \pm 6.20$ & $21.00-82.00 / 47.74 \pm 9.41$ & $0.84-2.62 / 1.52 \pm 0.70$ & $5.56-10.66 / 8.16 \pm 1.20$ & $3.00-7.40 / 4.25 \pm 1.01$ \\
\hline \multirow[t]{2}{*}{ Monsoon } & $0^{x}$ & 54 & $16.00-31.80 / 21.43 \pm 3.96$ & $33.00-61.00 / 43.74 \pm 7.80$ & $0.83-2.67 / 1.43 \pm 0.71$ & $5.50-10.37 / 7.50 \pm 1.22$ & $2.10-11.44 / 5.24 \pm 1.96$ \\
\hline & 90" & 81 & $14.00-38.00 / 22.97 \pm 5.65$ & $21.00-82.00 / 46.40 \pm 9.69$ & $0.84-2.67 / 1.48 \pm 0.70$ & $5.50-10.66 / 7.98 \pm 1.24$ & $2.10-11.44 / 4.91 \pm 1.77$ \\
\hline
\end{tabular}

Note: GW: Gonad weight; gutted weight: GtW.
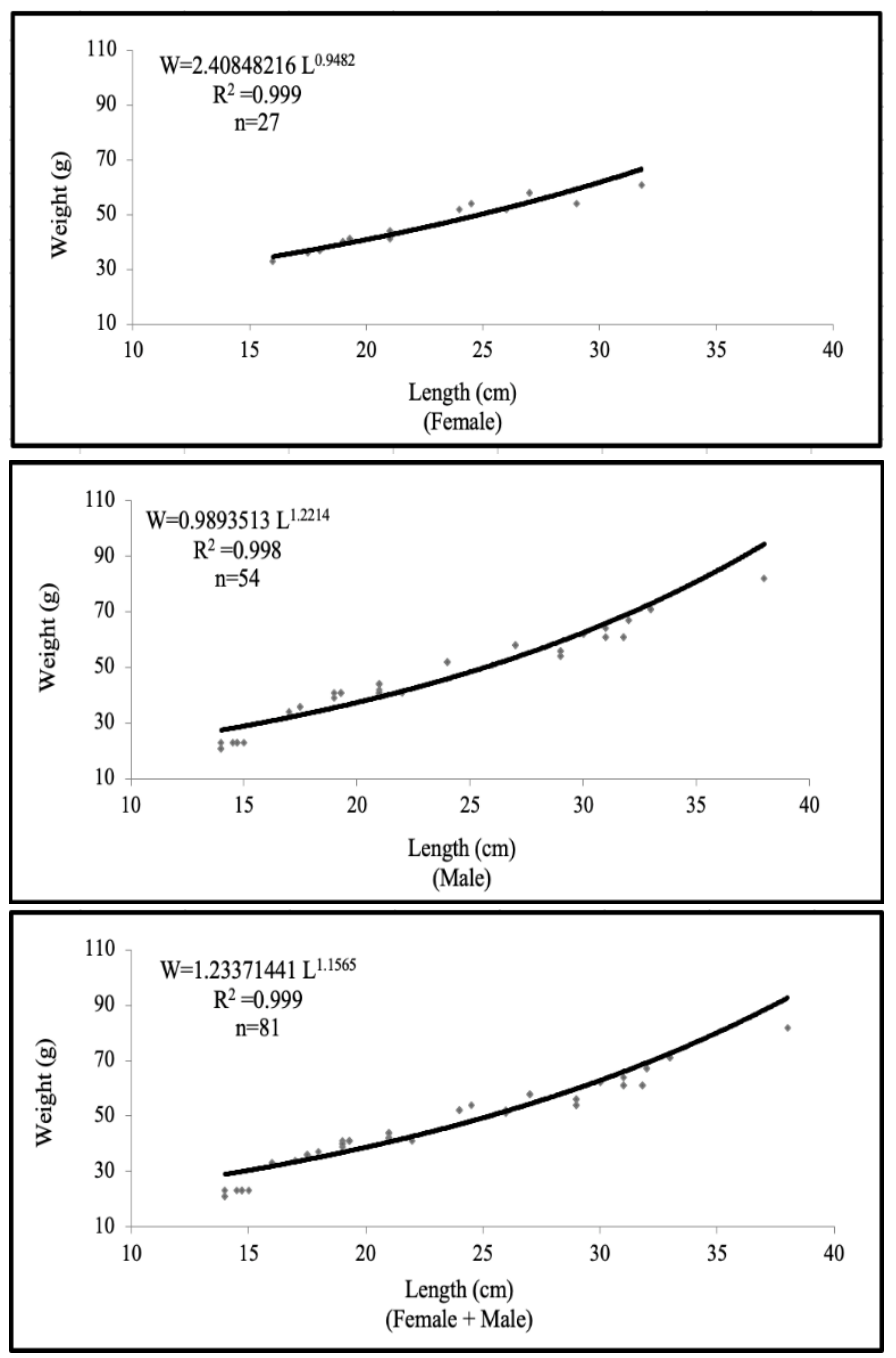

Figure 3. Length-weight relationships in female, male and all individual of sea cucumber
The condition factor and GSI distribution according to season and sex of sea cucumber are shown in Figure 4 and Figure 5, respectively.

The gutted weight-length and gutted weight-weight curves for females, males and all individuals according to sex of sea cucumber are drawn in Figure 6 and Figure 7, respectively.

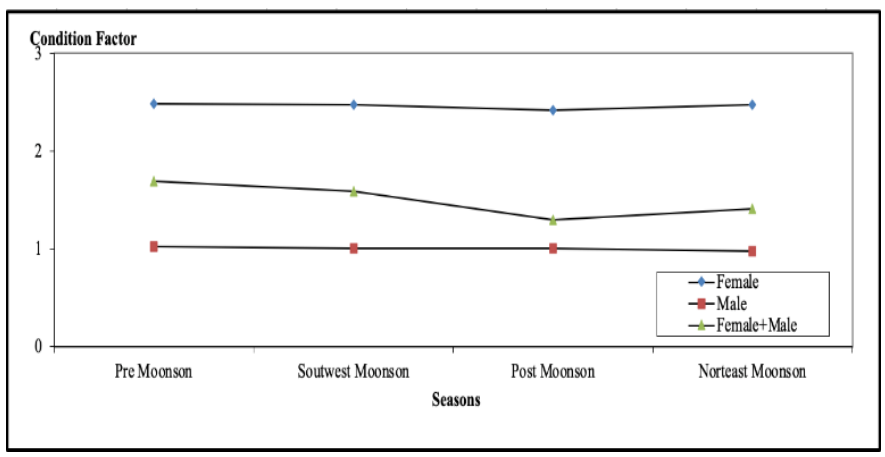

Figure 4. Condition factor according to season and sex of sea cucumber

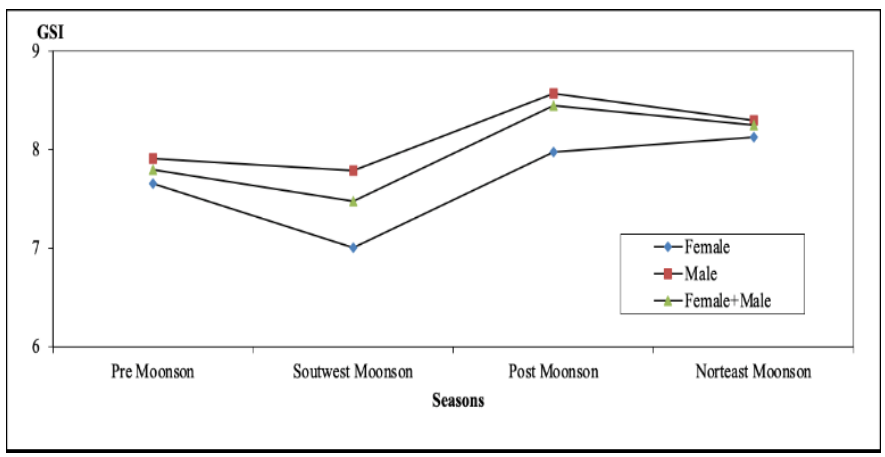

Figure 5. GSI according to season and sex of sea cucumber 


\section{Discussion}

The comparison of the length weight relationships parameters, $\mathrm{L}_{\max }, \mathrm{W}_{\max }$, gutted weight (GtW), gonadosomatic index (GSI) and condition factor (C) of sea cucumber species showed in Table 2. The slope (b) of length weight relation values calculated for Buleji were higher than literature (Razek et al., 2010; Ahmed et al., 2018). The b value was lower than Siddique et al. (2014, 2015). The $\mathrm{L}_{\max }$ value was lower than Ahmed et al. (2018) while $\mathrm{W}_{\max }$ values was lower than Ahmed et al. (2018) and Siddique et al. (2014, 2015) (Table 2). The b values in fish is species specific and varies with sex, age, seasons, physiological conditions, growth increment and nutritional status of fish (Bagenal and Tesch, 1978). Variations in fish growth in terms of length and weight can be explained as an adaptive response to different ecological conditions (Balık et al., 2009).

In this latest study conducted in the Karachi coast, it was reported that sea cucumber species such as $H$. atra and $H$. arenicola show rapid and seasonal growth characteristics (Ahmed et al., 2020). Allometric growth has been determined when the data are examined. As a general assumption, species grow isometrically, but commercial sea cucumber does not show isometric growth. $H$. arguinensis allometric growth has also been reported (González-Wangüemert et al., 2016). Therefore, comparing growth rates from different commercial species should be carefully evaluated.

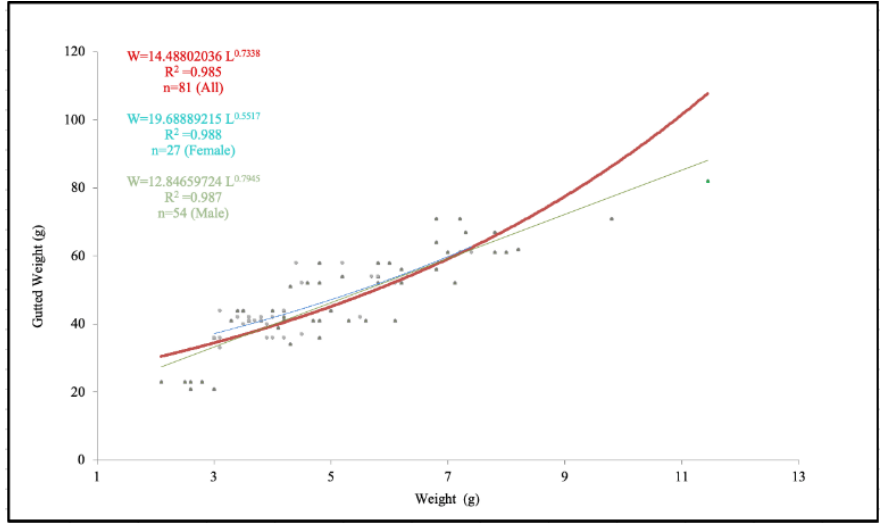

Figure 6. The gutted weight-length curves for females, males and all individuals

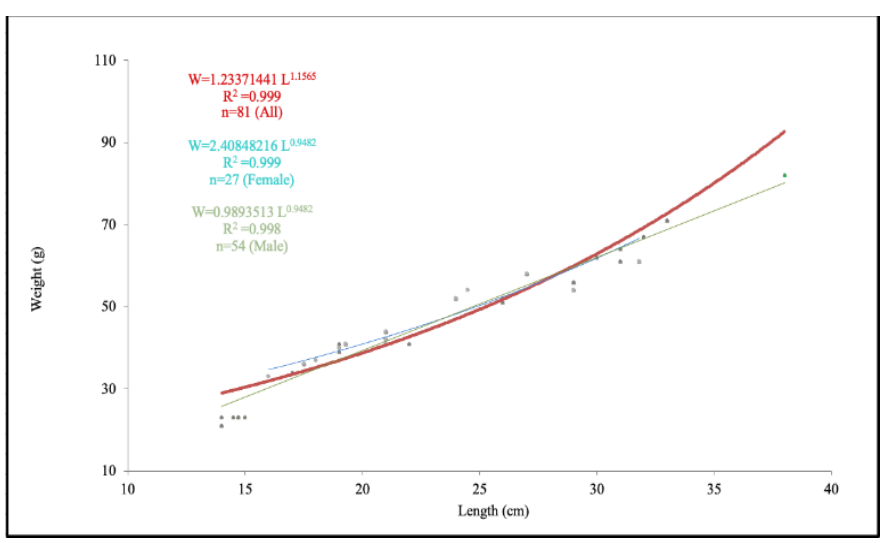

Figure 7. The gutted weight-weight curves for females, males and all individuals

Table 2. Comparison of sea cucumbers same parameters from different studies

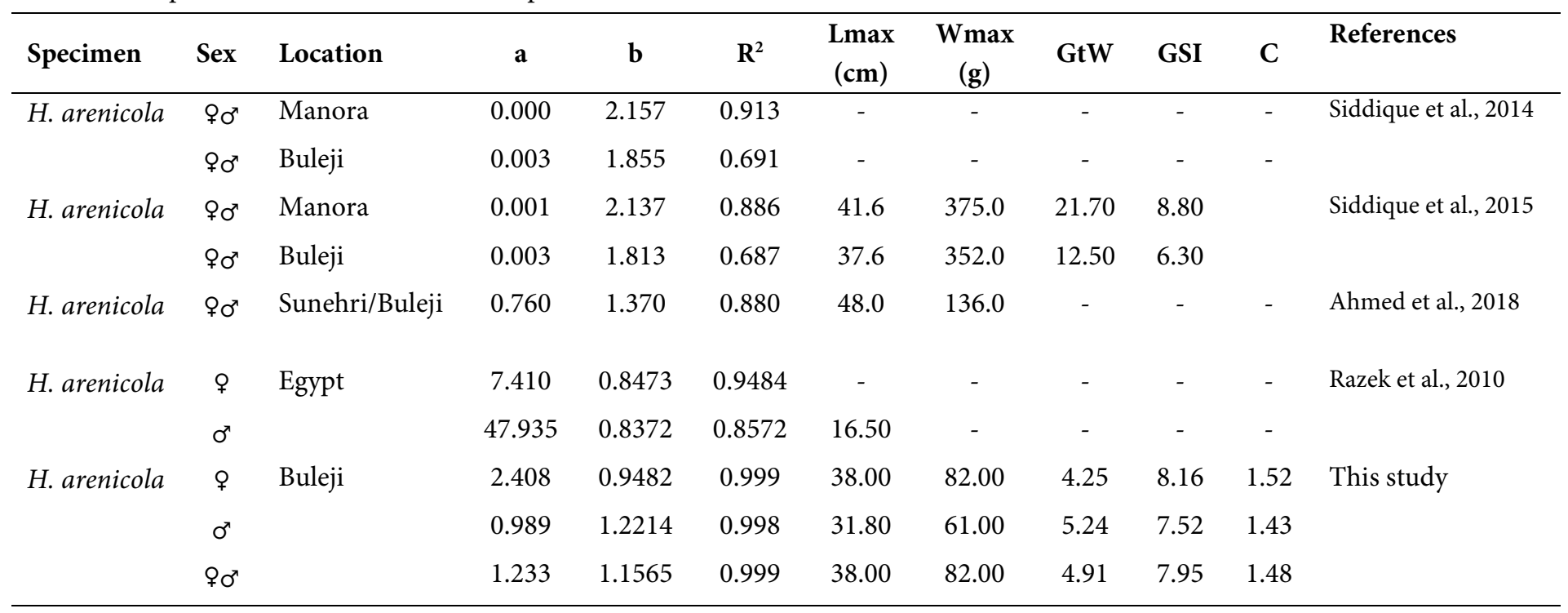

The mean values of length of sea cucumber of pre monsoon, southwest monsoon, post monsoon, northeast monsoon were $20.58 \pm 3.30 \mathrm{~cm}, 21.62 \pm 5.40 \mathrm{~cm}, 22.56 \pm 5.20 \mathrm{~cm}$, and $23.98 \pm 6.56$ $\mathrm{cm}$, respectively. The mean of weight of sea cucumber of pre monsoon, southwest monsoon, northeast monsoon, post monsoon was $41.46 \pm 8.97 \mathrm{~g}, 44.03 \pm 13.30 \mathrm{~g}, 48.14 \pm 14.80 \mathrm{~g}$, and
$51.11 \pm 9.56 \mathrm{~g}$, respectively. While the highest length average was observed in northeast monsoon, the highest weight average was determined in post monsoon. The lowest length and weight average were determined in pre monsoon (Table 1).

Gutted weight value of this study was lower than the value of Siddique et al. (2015). The results of gonadosomatic index 
value are in agreement with some earlier reports (Siddique et al., 2015). LWR and C parameters offer valuable information for understanding the biology and ecology of fish in terms of predicting the average weight corresponding to a known length group (Froese, 2006).

The lowest $\mathrm{C}$ value (1.30) was found in the post monsoon, while the largest $C$ value (1.68) was found in the pre monsoon. The higher GSI value (8.45) was found in the post monsoon, while the lower GSI value (7.48) was seen in the South monsoon (Figure 4 and Figure 5).

\section{Conclusion}

This study provides knowledge on certain biological aspects of Holothuria arenicola, which can be utilized for effective management measures (monitoring and hunting) in order to avoid the over exploitation of this species. Studies about environmental variables and characteristics are necessary in order to complement the understanding of the length-weight relationships and condition of sea cucumber in Karachi coast.

\section{Acknowledgements}

This study was written while at home quarantine during the COVID-19 pandemic.

\section{Compliance with Ethical Standards}

\section{Authors' Contributions}

QA, SB and QMA performed the research, analyzed the data and helped to draft the manuscript; QA and SB conceived and designed the work and wrote the manuscript. All authors contributed to and approved the final manuscript.

\section{Conflict of Interest}

The authors declare that there is no conflict of interest.

\section{Ethical Approval}

For this type of study, formal consent is not required.

\section{References}

Ahmed, Q., Bilgin, S. \& Ali, Q. M. (2020). Comparison of electronic length frequency analysis (ELEFAN) for estimation of growth parameters for lollyfish, Holothuria (Holothuria) atra and sand sea cucumber, Holothuria (Thymiosycia) arenicola (Holothuroidea: Echinodermata) in the north Arabian Sea, Pakistan. Marine Science and Technology Bulletin, 9(2): 145-158. https://doi.org/10.33714/masteb.744301
Ahmed, Q., Ali, Q. M., Mazlan, N. \& Bat, L. (2018). First record of a-sexual reproduction by fission in Holothuria (lessonothuria) verrucosa (Selenka, 1867) from Coastal Waters of Karachi, Pakistan. International Journal of Environment and Geoinformatics, 5(1): 29-36. https://doi.org/10.30897/ijegeo.353267

Ahmed, Q., Bilgin, S. \& Bat, L. (2016). Length based growth estimation of most commercially important Scombridae from offshore water of Pakistan coast in the Arabian Sea. Turkish Journal of Fisheries and Aquatic Sciences, 16: 155-167. https://doi.org/10.4194/1303-2712-v16_1_16

Ahmed, Q., Poot-Salazar, A., Ali, Q. M. \& Bat, L. (2018). Seasonal variation in the length-weight relationships and condition factor of four commercially important sea cucumbers species from Karachi coast-Northern Arabian Sea. Natural and Engineering Sciences, 3(3): 265-281. https://doi.org/10.28978/nesciences.468667

Aydın, M. (2016). Sea cucumber (Holothuroidea) species of Turkey. Turkish Journal of Maritime and Marine Sciences, 2(1): 49-58.

Bagenal, T. B. \& Tesch, F. W. (1978). Age and growth (pp. 101136). In: T. Bagenal (Ed.), Methods for assessment of fish production in fresh waters. IBP Handbook No. 3. Oxford, UK: Blackwell Scientific Publications.

Balık, İ., Çubuk, H., Çınar, Ş. \& Özkök, R. (2009). Population structure, growth, mortality and estimated stock size of the introduced tench, Tinca tinca (L.), population in Lake Beyşehir, Turkey. Journal of Applied Ichthyology, 25: 206-210. https://doi.org/10.1111/j.14390426.2009.01213.x

Clarke, S. (2004). Understanding pressures on fishery resources through trade statistics: A pilot study of four products in the Chinese dried seafood market. Fish and Fisheries, 5: 53-74. $\quad$ https://doi.org/10.1111/j.1467-2960.2004. 00137.x

Conand, C. (1989). The fishery resources of Pacific Island countries. Part 2. Holothurians. FAO Fisheries Technical Paper No. 272. 2: 143.

Conand, C. \& Gamboa, R. (2013). Holothuria arenicola. The IUCN Red List of Threatened Species 2013: e.T180437A1630561.

Froese, R. (2006). Cube law, condition factor and weight length relationships: history, meta-analysis and recommendations. Journal of Applied Ichthyology, 22: 241-253. $\quad$ https://doi.org/10.1111/j.1439-0426.2006. 00805.x 
Gerritsen, H. D. \& McGrath, D. (2007). Significant differences in the length-weight relationships of neighbouring stocks can result in biased biomass estimates: Examples of haddock (Melanogrammus aeglefinus, L.) and whiting (Merlangius merlangus, L.). Fisheries Research, 85: 106111. https://doi.org/10.1016/j.fishres.2007.01.004

González-Wangüemert, M., Valente, S., Henriques, F., Domínguez-Godino, J. A. \& Serrão. E. A. (2016). Setting preliminary biometric baselines for new target sea cucumbers species of the NE Atlantic and Mediterranean fisheries. Fisheries Research, 179: 57-66. https://doi.org/10.1016/j.fishres.2016.02.008

Hannah, L., Duprey, N., Blackburn, J., Hand, C. M. \& Pearce, C. M. (2012). Growth rate of the California Sea cucumber Parastichopus californicus: Measurement accuracy, and relationships between size and weight metrics. North American Journal of Fisheries Management, 32: 167-176. https://doi.org/10.1080/02755947.2012.663455

Herrero-Pérezrul, M. D. \& Reyes-Bonilla, H. (2008). Weightlength relationship and relative condition of the Holothurians Isostichopus fuscus at Espíritu Santo Island, Gulf of California, México. Revista de Biología Tropical, 56(Suppl 3): 273-280.

Kazanidis, G., Antoniadou, C., Lolas, A. P., Neofitou, N., Vafidis, D., Chintiroglou, C. \& Neofitou, C. (2010). Population dynamics and reproduction of Holothuria tubulosa (Holothuroidea: Echinodermata) in the Aegean Sea. Journal of the Marine Biological Association United Kingdom, 90(5): 895-901. https://doi.org/10.1017/S0025315415000041

Kilada, R. W., Abdel Razek, F. A. \& Yassin, M. H. (2000). Population growth and sexual reproduction of the sea cucumber Holothuria arenicola from the Eastern Mediterranean Egypt. Journal of Aquatic Bulletin \& Fisheries, 4(4): 119-135. $\quad$ https://doi.org/10.1017/ $\underline{\mathrm{S} 0025315415000041}$

Mosher, C. (1980). Distribution of Holothuria arenicola Semper in the Bahamas with observations on habitat, behavior, and feeding activity (Echinodermata: Holothuroidea). Bulletin of Marine Science, 30: 1-12

Natan, Y., Uneputty Pr, A., Lewerissa, Y. A. \& Pattikawa, J. A. (2015). Species and size composition of sea cucumber in coastal waters of UN Bay, Southeast Maluku, Indonesia. International Journal of Fisheries and Aquatic Studies, 3(1): 251-256.
Poot-Salazar, A., Hernảndez-Flores, Á. \& Ardisson, P. L. (2014). Use of the SLW index to calculate growth function in the sea cucumber Isostichopus badionotus. Scientific Reports, 4(5151): 1-7. https://doi.org/10.1038/ $\underline{\text { srep05151 }}$

Purcell, S. \& Tekanene, M. (2006). Ontogenetic changes in colouration and morphology of white teat fish, Holothuria fuscogilva, juveniles in Kiribati. SPC Bechede-Mer Information Bulletin, 23: 29-31.

Purcell, S. W. (2010). Managing sea cucumber fisheries with an ecosystem approach to managing sea cucumber fisheries. FAO Fisheries and Aquaculture Technical Paper No.520, Rome, FAO, 157 p.

Purcell, S. W., Samyn, Y. \& Conand, C. (2012). Commercially important sea cucumbers of the world, FAO Species Catalogue for Fishery Purposes, No. 6, FAO, Rome. 150 p.

Ram, R., Chand, R. V. \& Southgate, P. C. (2016). An overview of sea cucumber fishery management in the Fiji Islands. Journal of Fisheries and Aquatic Sciences, 11: 191-205.

Razek, F. A., Mona, M. H., Abdel Rahman, S. H., El Gamal, M. M., Moussa, E. M. \& Taha, S. M. (2010). Observations on the abundance of holothurian species along the Alexandria coast of Eastern Mediterranean waters. Proceedings of the $89^{\text {th }}$ CIESM Congress-Venice, May 10-14,2010, ltaly.

Siddique, S. \& Ayub, Z. (2019). To estimate growth function by the use of SLW index in the sea cucumber Holothuria arenicola (Holothuroidea: Echinodermata) of Pakistan (Northern Arabian Sea). Thalassas: An International Journal of Marine Sciences, 35(1): 123-132. https://doi.org/10.1007/s41208-018-0099-5

Siddique, S., Ayub, Z. \& Siddiqui, G. (2014). Length-weight relationship and condition factor in Holothuria arenicola (Holothuroidea: Echinodermata) found on two rocky coasts of Karachi, Pakistan. Pakistan Journal of Marine Sciences, 23(1\&2): 51-63.

Tahera, Q. \& Tirmizi, N. M. (1995). A new record of Holothuria (Thymiosycia) arenicola Semper, 1868 (Echinodermata: Holothuroidea) from Pakistan. Raffles Bulletin of Zoology, 43: 217-220. 